(B.M.F. in press) immunosuppression has been managed on the basis of regular white cell counts with acute rejection episodes diagnosed on biochemical and clinical grounds One patient has died, five nephrectomies have been performed, and the remaining 27 patients $(82 \%)$ are alive and well at from three years to six months posttransplant. We feel from our research experience that the rosette inhibition test is not sensitive or accurate enough as an index of "immune status" to be used as the basis of patient management in clinical renal transplantation.-We are, etc.,

R. F. M. WOOD AILEEN GRAY P. R. F. BELL

J. D. BRIGGS

Renal Unit and Department of Surgery,

Western Infirmary,

Glasgow

1 Munro, A., et al., British Medical fournal, 1971 3, 271.

hren, S. F. G., and MacLean,

\section{Allergy to House-dust Mites in the Tropics}

SIR,-Asthma is a common problem in tropical medical practice. ${ }^{12}$ In our experience it was the third most common cause of male medical admissions to Ndola Central Hospital in 1971. The 172 male asthmatic admissions represented $9 \%$ of the total male medical admissions during that year and provided a disproportionately heavy clinical load with numerous readmissions and resistance to the usually employed bronchodilators.

Allergy to house-dust mites has been convincingly demonstrated as a cause of asthma, ${ }^{3}$ and it has been stated to be an important factor in the aetiology of asthma in the tropics. ${ }^{14}$ This preliminary study was designed to test the validity of this hypothesis.

Ndola lies at an altitude of 1,280 metres, latitude $13^{\circ} \mathrm{S}$., and is the commercial and distributive centre of Zambia's copperbelt. Admissions to hospital of asthma cases are greatly increased during the wet season (November-April), when the relative humidity is high (Table I). The climatic conditions of the wet season provide favourable conditions for mite growth whereas the low relative humidity of the dry season (May-October) is unfavourable. ${ }^{3}$

TABLE I-Mean $\begin{gathered}\text { Monthly Temperature, Relative } \\ \text { Humidity, and Total Monthly Asthma Admissions }\end{gathered}$ for 1971

\begin{tabular}{l|c|c|c}
\hline Month & $\begin{array}{c}\text { Mean } \\
\text { Temperature }\end{array}$ & $\begin{array}{c}\text { Relative } \\
\text { Humidity }\end{array}$ & $\begin{array}{c}\text { Total Asthma } \\
\text { Admissions }\end{array}$ \\
January & 20.1 & 83 & 16 \\
February & 20.4 & 81.5 & 31 \\
March & 20.8 & 75.2 & 61 \\
April & 20.8 & 70 & 42 \\
May & 18.2 & 51 & 28 \\
June & 16.3 & 50 & 20 \\
July & 17.2 & 49 & 8 \\
August & 19.5 & 39 & 5 \\
September & 22.0 & 40 & 12 \\
October & 23.4 & 41.1 & 7 \\
November & 21.4 & 69.3 & 9 \\
December & 20.6 & 78.4 & 13 \\
& & &
\end{tabular}

Thirty unselected adult Zambian African asthmatics ( 25 men, 5 women) were tested by the modified prick test using an extract of Dermatophagoides farinae prepared by Bencard and compared with 30 controls matched for sex, age, and smoking history

TABLE II-Reaction of Asthmatic Patients and Controls to Prick Test with Dermatophagoides farinae

\begin{tabular}{l|rr|r}
\hline & \multicolumn{2}{|c|}{ Reaction } & \\
\cline { 2 - 4 } & Positive & Negative & Total \\
\hline Asthmatics & 25 & 5 & 30 \\
Controls & 4 & 26 & 30 \\
Total & 29 & 31 & 60 \\
\hline
\end{tabular}

$\chi^{3} 26.7$; D.F. $1 ; P<0.0005$

(Table II). Twenty-five of the 30 asthmatics $(83 \%)$ gave a positive reaction to the allergen, but only four of the 30 controls $(13 \%)$ were positive, a statistically highly significant difference $\left(\chi^{2} 26.7\right.$, D.F. $1, P<$ $0.0005)$. All the asthmatics were asked to collect a dust specimen from their sleeping area. Of the 18 specimens received 11 had live mites of Dermatophagoides species present. Both $D$. pteronyssinus and $D$. farinae were identified. In three others only mites of the species Glycophagus and Cheyletus were found.

These results suggest that allergy to housedust mites is a very significant factor in the aetiology of asthma in Ndola, and this is probably so elsewhere in tropical Africa where asthma is common. No attempt was made to skin test the asthmatics with other allergens. This has been done on Nigerians on a limited scale with inconclusive results. Further studies are indicated to assess the possible importance of these other allergens.

If the results of this study are confirmed it would seem reasonable to embark on a trial of hyposentitization, as this has been shown to be of some benefit, ${ }^{5}$ and to examine the possibility of mite eradication.-We are, etc.,

Douglas J. BuchanaN IAN G. JONES

Central Hospital

Ndola, Zambia

1 Sofowora, E. O., East African Medical fournal, $1970,47,434$.

Anim, J, T. and Edoo, B. B., Ghana Medical Fournal, 1972, 11, 59.

Gitoho, F., and Rees, P., British Medical fournal, 1971, 3, 475 . Maunsell, K., Wraith, D. G., and Hughes, A. M.
Lancet, 1971, 1, 967.

\section{Chinese Heroin}

SIR,-In the light of recent press reports of a large scale importation of impure Chinese heroin to Britain via Hong Kong the following case is disturbing.

Previously treated for reactive depression attributed to frustration in her employment as a children's nurse in 1967, a 22-year-old married woman was referred after returning from London to her mother's Blackpool home. Introduced to intravenous heroin and physeptone by her boy-friend-later husband - two years ago, she obtained supplies of impure Chinese heroin from the wife of a Chinese pusher. She stated that rapidly increasing tolerance caused her to increase the dose sixtyfold ( 1 ounce $(7.7 \mathrm{~g})$ daily). She developed amenorrhoea and abscesses and thrombophlebitis in both arms and her general condition deteriorated, with weight loss of $20 \mathrm{lb}(9 \mathrm{~kg})$. Her husband was admitted to a London clinic for treatment of heroin addiction. She insisted that since returning to Blackpool she had taken only a tiny dose of Chinese heroin, about the source of which she was very reticent, and experienced some withdrawal symptoms-cold- ness, sweatiness, pains in the abdomen, and constipation.

Until recently virtually all heroin in this country ultimately came from medical sources, formerly from prescribing and latterly from the treatment centres themselves. ${ }^{1}$ To some extent this limited the spread of addiction and the purity of the drug reduced the likelihood of adverse clinical effects. Moreover, it is assumed that addicts seeking supplies will thus attend the drug-dependence centres. Now we are confronted with pushing by people supplied by allegedly extensive illegal imports. If so, we have a situation similar to that in the United States, where there has been an epidemic of addiction with disastrous social and medical effects. Furthermore, the stimulus for addicts to seek treatment may well be lessened.

That this patient came to Blackpool and was still able to obtain supplies suggests that this addiction may spread through the country. In view of these clinical and epidemiological considerations it is disturbing that notification of heroin addicts to the Department of Health through the hospitals concerned, begun in July 1967, was discontinued in January 1971, though notification to the Home Office under the terms of H.M.(68)6 remains. ${ }^{2}-\mathrm{I}$ am, etc.,

St. Annes-on-Sea

M. W. P. CARNEY

Lancs

Gardner, R., and Connell, P. H., Lancet, 1970

2,455 .
Home Office, The Dangerous Drugs (Notification of Addicts) Regulations 1968. London, H.M.S.O.
H.M.(68)6.

\section{School Refusa}

SiR,-Dr. Lionel Hersov (8 July, p. 102) might have found space to mention more specifically the management roles of the general practitioner and the school medical officer. At primary care level they are community physicians co-operating in the fields of paediatric mental health and infectious disease control. Subject to the interest they show, they may or may not need to involve psychiatric or child guidance staff. Many cases are resolved without resort to the advice of either. Dr. Max B. Clyne ${ }^{1}$ illustrates this point.

As Mrs. Diana J. Leigh (22 July, p. 236) and Dr. G. L. Davies (29 July, p. 293) point out, the trigger factor in a multifactorial aetiology is usually social (for example, change of school or illness of a relation). However, the social worker most likely to be involved is specifically the educational welfare officer. $\mathrm{He}$ is not part of the postSeebohm social services department but at present is an educational department colleague of the school medical officer working for the same local authority. $\mathrm{He}$ is thus well placed to cope with those children for whom social and medical advice may be necessary or on whose behalf legal proceedings may need to be taken. The early determination of the very difficult problem of which children are challenging authority as truants (and therefore potential behaviour or conduct problems with later personality disorders) is very important indeed. Dr. Hersov has himself given very useful and valuable advice on this aspect, which has in practice been found to work. ${ }^{2}$

These children are problematic in more 